\title{
Study on the Levels of Some Essential and Non-essential Metals in Four Different Varieties of Barley (Hordeum Vulgare 1.), Grown at the Farm Site in Dale and Aletawondo Woredas, in Sidamo Zone, Ethiopia
}

\author{
Bekele Gelagay $^{1} \quad$ Madhu thomas ${ }^{2}$ \\ 1.Department of chemistry, Hawassa University, PO box 05, Hawassa, Ethiopia \\ 2.Department of chemistry, Addis Abeba science and technology University, PO box , Addis Abeba, Ethiopia
}

\begin{abstract}
A study was conducted to determine the concentration of essential and non-essential metal accumulation in four different barley varieties grown at the farm site in Dale and Aleta wondo woredas, in sidama zone, Ethiopia using flame atomic absorption spectrophotometer. In this research wet ashing method used to destroy the organic matrix. The mineral concentration of four Ethiopian barley varieties was studied, namely: Semereta, Nech, Senef and Bera barley varieties. Among all the varieties; Semereta showed the highest K, Mg content $(4434.86 \pm 176.92$, $757,57 \pm 36.43)$ respectively. Nech showed the highest $\mathrm{Ca}$, Zn content (1347.48 $\pm 483.1980 .54 \pm 8.66)$ respectively. Senef showed the highest $\mathrm{Cu}$, Ni content $(6.88 \pm 0.52,1.86 \pm 0.33)$. These results may be useful in the food industry for the selection of hull barley varieties for human consumption and for animal feed as supplement of grass. Validation of the method checked by using recovery test of the digestion method.
\end{abstract}

Keywords: Atomic absorption spectrophotometer, barley, essential, non-essential, wet ashing method.

DOI: $10.7176 / F S Q M / 83-03$

\section{Introduction}

\subsection{Back ground of the study}

The world has now re-discovered barley (Hordeum vulgare L.) as a food grain with desirable nutritional composition including some medicinal properties. Barley ranks fifth among field crops in grain production in the world after maize, wheat, rice and soybean. In recent years, about two thirds of barley crop has been used for feed, one-third for malting and about $2 \%$ directly for food [1].

In Ethiopia, barley is the third most important cereal crop next to teff and maize. It is commercially used for making local beer, Injera (Ethiopian flat bread), Kolo (roasted barley), for animals feed and in brew factory as a row material. Barley breakfast foods and snacks are increasingly available, driven by recent research findings, which show that barley fiber contains beta-glucans and tocotrinols, chemical agents known to lower serum cholesterol levels in the blood [2].

Barley grains have a hull of adherent pales, which are removable only with difficulty in hulled forms. In naked forms, the hull is readily lost during threshing. The hull amounts to about $13 \%$ of the grain (by weight) on average, the proportion ranging from 7 to $25 \%$ according to type, variety, grain size, and latitude where the barley is grown. The factors, which regulate the growth of plants are depend on a number of a biochemical processes involving various inorganic elements present in the soil. Large variation in mineral content of different crops depends upon plants species, nutrient availability, soil and climate. The plant species vary widely in tolerance to toxic metals and varieties with a species can also vary three to ten folds. Variation in mineral content of different plant species grown on the same soil has also been reported. [3].

During the past several decades, there has been increasing concern regarding the accumulation of heavy metals in the terrestrial environment. Contamination of soils with heavy metals is widespread in the world and poses a long-term risk to ecosystem health. Soil can affect human health adversely in several ways: it can cause illness by entering the body directly through its consumption. Elements from the soil may enter the human body through the food chain and through water intake. Heavy metals can occur in concentrations that are either toxic or deficient, both leading to illness [4].

The term "heavy metals" refers to any metallic element that has a relatively high density and is toxic or poisonous even at low concentration. "Heavy metals" is a general collective term, which applies to the group of metals and metalloids with atomic density greater than $4 \mathrm{~g} / \mathrm{cm}^{3}$, or 5 times or more, greater than water. However, being a heavy metal has little to do with density but concerns chemical properties. Heavy metals include lead $(\mathrm{Pb})$, cadmium $(\mathrm{Cd})$, zinc $(\mathrm{Zn})$, mercury $(\mathrm{Hg})$, arsenic $(\mathrm{As})$, silver $(\mathrm{Ag})$, chromium $(\mathrm{Cr})$, copper $(\mathrm{Cu})$, iron $(\mathrm{Fe})$, and the platinum group elements.

Metal pollutants can be classified as either essential elements (important for life) or nonessential elements (with no known physiological functions to humans) and sometimes incorrectly referred to toxic metals. Nonessential metals (NEMs) are priority pollutants that pose potential risks to human health and the environment. Exposure to NEMs such as arsenic, cadmium, lead and mercury has been associated with a significant number of 
adverse health effects in humans [5].

Following Mason and Jenkins (1995), I divided here the analyzed elements as essential elements (Ca, K, $\mathrm{Mg}, \mathrm{Mn}, \mathrm{Cr}, \mathrm{Co}, \mathrm{Ni}$, and $\mathrm{Zn}$ ) and non-essential elements ( $\mathrm{Cd}$ and $\mathrm{Pb}$ ) [6]. Toxic metals include Arsenic, Antimony, cadmium, chromium, cobalt, lead, $\mathrm{Mn}, \mathrm{Cu}, \mathrm{Fe}, \mathrm{Hg}, \mathrm{Ni}, \mathrm{Se}$, thallium, beryllium, plutonium. Some metals such as $\mathrm{Cr}, \mathrm{Se}, \mathrm{Co}, \mathrm{Mn}$ and $\mathrm{Ni}$ are essential as well as toxic depending on their contradictions and tolerance limit of the organism.

Minerals in foods are usually determined by ashing or incirination this destroy the organic compounds and leave the minerals behind. Cadmium is a nonessential, potentially toxic, large pollutant ion and is accumulated in plants. In addition, phosphates, which are used in cereal cultivation, contain high concentrations of heavy metals. The use of phosphate fertilizers constitutes a basic factor of pollution of agricultural soils. Soils repeatedly receiving these materials have exhibited high concentrations of heavy metals $[4,6]$.

The contamination of plants by toxic heavy metals has a major impact on both the environmental cycling of nutrients and the quality of food stuffs. Plants can accumulate trace elements, especially heavy metals, from soils, waters or air. There is a wide variability in the bioaccumulation of trace elements among different plant species. For example, some elements such as $\mathrm{B}, \mathrm{Cd}, \mathrm{Rb}$ and $\mathrm{Cs}$ are readily taken up, whereas $\mathrm{Fe}$ and $\mathrm{Se}$ are only slightly available to plants [7].

Metal concentrations in cereal crops have been found to be influenced by such factors as soil type, soil $\mathrm{pH}$, and plant genotype, stalk position, soil and leaf residues resulting from the application of pesticides containing metals and from soil amendments, including fertilizers and municipal sludge. Soil $\mathrm{pH}$ is generally the most important factor determining plant uptake of trace metals, whose mobility is most often greater under acid conditions. Therefore, heavy-metal contamination is likely to be a bigger concern in acid soils. Depending on the soil properties, the chemical forms of metals in soil can vary and influence plant uptake. Before making the decision of what measures should be taken, it is important to know the levels of heavy metals in cereals and the possible impact on human's health. It is essential to make a correct evaluation of the contaminated status of cereals for special strategies for controlling quality of crop products. Minerals are inorganic substances, present in all body tissues and fluids and their presence is necessary for the elements or minerals for the normal life processes [8].

\section{2. Objectives}

\section{2. 1. General objectives of the study}

The purpose of this research was to examine the concentration of essential and non essential metals in different barley cultivars; one of the varieties commonly used for malting in brew factory (Bera barley) and three of the verities which are commonly used as a food item for the inhabitants was investigated. So that it is possible to look after their nutritional role as a source of food for humans and animals feed and to know the future possible measurements that might be taken for corrective action to improve the health problems of the animals and peoples.

\subsection{Specific Objectives of the study}

- $\quad$ To determine the concentrations of $\mathrm{K}$ in different barley varieties using emission mod of FAAS.

- $\quad$ To determine non-essential metal concentrations $(\mathrm{Cd}$ and $\mathrm{Pb})$ of different barley varieties.

- $\quad$ To compare essential $(\mathrm{K}, \mathrm{Mg}, \mathrm{Ca}, \mathrm{Cu}, \mathrm{Zn}, \mathrm{Co}, \mathrm{Cr}$ and $\mathrm{Ni})$ and non essential $(\mathrm{Cd} \mathrm{Pb})$ metal concentrations of different barley varieties with the permissible values of metal concentrations.

- To know the distribution of the metals in different varieties of barley varities.

- To Safe guard the health of the consumer from the effect of accumulation of non essential nutrients.

\section{Literature review}

\subsection{Classification and distribution of barley in Ethiopia}

The barley genus, Hordeum $l$., is a relatively small genus with about 28 species distributed over wide geographical areas and diverse ecological habitats. According to Modern treatment, hordium vulgare L. is differentiated in to two sub species: spontaneum and vulgare. The former subspecies contains the entire spontaneum group and is the immediate ancestor of all cultivated types. The main feature distinguishing between the two subspecies is that the spontaneum types have brittle rachis while the vulgare types have tough rachis. In Ethiopia; it is observed that farmers and communities more frequently use barley groups based on differences of caryopsis or kernel type. Caryopsis type is one character that is used for barley classification both under the traditional and the modern systems that is easier for routine application. [9].

Sorting on the bases of caryopsis types provides neat and more expressive system by which the following three groups are easily distinguished by Ethiopian farmers. Hulled barley: In this group the husk adheres to the grain requiring laborious dehulling to make it ready for human consumption. Hulled and partially hulled types account about $70 \%$ of the morphological distinct barley types in Ethiopia. It is the most diverse category including six row, irregular forms, dense, lax, hooded, long awn and short awn, rough awn and smooth awn, etc. 
Hull less barley: The hull less (naked) barley is a group in which the husk falls free on trashing with out adhering to the grain. Naked types are cultivated in the highlands of shewa gondar and tigry. Hull less barley mainly used for food with superior nutritional quality with respect to proteins fates minerals dietary fiber and energy.

Partially hulled barley: This constitutes a diverse group of two barley with lax and dense forms in which the husk is easily removed up on heating. This group is encountered in many regions but most frequently in hilandes of showa gamogofa gondar and bale the partially hulled grains most preferable for consumption in the form of roasted grains $[9,10]$

Barley is one of the oldest cultivated crops and has been grown in Ethiopia for at least 5000 years and it is cultivated in all regions of the country. The most important barley producing regions are Shewa, Arsi, Gojam, Gonder, Welo, Bale and Tigray, where more than $85 \%$ of the country total production comes from. Variation of disease resistance, Genes related with high lysine, malting and brewing quality were reported by different authors. Demissie and Bjørnstad (1996) found morphological diversity for different traits in relation with regions, altitudes and agro-ecological zones for a total of 51 barley populations. Barley is grown primarily for local food and beverage consumption. For small scale highland farmers, barley is the predominant subsistence crop [11].

In Ethiopia barley can be cultivated at altitudes between 1500 and $3500 \mathrm{~m}$ but is predominately grown between altitudes of 2000 and $3000 \mathrm{~m}$. On the whole the southern and southeastern highlands harbor more morphotypes found than the central and northern highlands. However, some individual localities within both zones (e.g., Kembata, Galessa-Tululencha, Chen-cha) are recognized as pockets of higher number of morphotypes per field, as illustrated by a study carried out in Jibat and Mecha revealing higher number of morphotypes per field and in the entire locality [9,11]. Barley is arguably the most widely adapted cereal grain species with production at higher latitudes and altitudes and farther into deserts than any other cereal crop. It is in extreme climates that barley remains a principal food source today, e.g., Himalayan nations, Ethiopia, and Morocco [12].

Food barley is generally found in regions where other cereals grow poorly due to low rainfall, altitude, or soil salinity. It remains the most viable option in dry areas $(<300 \mathrm{~mm}$ of rainfall $)$ and in production systems where alternative food crops are limited, such as in the highlands and the mountains. Useful characteristics of Ethiopian barley include tolerance to marginal soil conditions and resistance to barley shoot flies and frost. Ethiopian barley shows sensitivity to lodging, low grain to straw ratio and fragile Richs. Barley production is constrained by several problems such as poor soil fertility, water logging, moisture stress, low field potential of currently growth cultivars and instability of yield because of disease insect pest and weeds. The crop has also quality related problems including poor malting quality; because of high protein, low extract and thin grains, tedious operation in food processing and a slight bitterness of grain for Injera, preparation. Several high yielding food and malting barley varieties have been known some of the released varieties are shown below $[12,13]$. Table1. Barley varieties in Sidamo zone which can be used for brew factories as arrow material

\begin{tabular}{|l|l|l|l|l|}
\hline \multirow{2}{*}{ No } & Local names of Varieties collected & Characteristics & Common use \\
\cline { 2 - 3 } & Amharic & Sidamic & hull less, small seed & \\
\hline 1 & Bera gebse & Bera gebse & hulled, yellow color & Malting \\
\hline 2 & Semereta gebse & Goso gebse & Partially hulled barley, mixed type & Roasted grain \\
\hline 3 & Senef gebs & Bullo gebse & very white and attractive & Food \\
\hline 4 & Nech gebs & Wajo haite & . \\
\hline
\end{tabular}

\section{2. Mineral Source of barley crop}

High concentrations of heavy metals in agricultural soils can occur naturally, or via the application of metal-rich sewage sludges, farmyard manures, $\mathrm{P}$ fertilizers and/or atmospheric deposition. With regard to human health, the cadmium $(\mathrm{Cd})$ and lead $(\mathrm{Pb})$ concentrations of agricultural products are of particular concern. Recent research suggests that 30 tons of $\mathrm{Cd}$ and 540 tons of $\mathrm{Pb}$ are added annually to agricultural soils in England. A number of investigators have shown that the long-term application of Cd-containing fertilizers may increase $\mathrm{Cd}$ uptake by crops [14].

Natural and anthropogenic sources of soil contamination are widespread and variable. Heavy metals occur naturally in rocks. Mineral rock weathering and anthropogenic sources provide two of the main types of metal inputs to soils. In localized mineral zones or around volcanoes an elevated level of the elements arsenic, lead, cadmium, copper and zinc can also be found [15].

But most crops with high calcium demand are also high sensitive to relatively high concentration of aluminum or manganese ions typically present in acidic soils. Farm yard manure also contains all the trace elements needed by plants for growth and dressing of $25 \mathrm{t} / \mathrm{h}$ will put back about the amount that has been removed by crops.

Organic and inorganic fertilizers change the crop quality according to their different potential abilities. Inorganic fertilizers are generally more soluble and available at the high plant demand, but organic manure 
releases minerals slowly which may not be fully available during the critical period of plant demand. Micronutrient concentration rate could be changed through inorganic or organic fertilizer application, by the influence on soil $\mathrm{pH}$ or increasing the organic matter content of the soil. There is a tendency in developed countries to reduce environmental risk and enhance food nutritional value by using more organic fertilizers, while in developing countries; low soil fertility limits the use of organic fertilizers. Uptake of copper, zinc and manganese by plants is affected by the level of phosphate fertilizer, while the chemical form of nitrogen fertilizer has been reported to affect the uptake of copper [1,8, and 16].

A toxic concentration of heavy metals is not known in agricultural soils; however, land disposal of wastes as soil amendments for crop production is responsible for temporal accumulation of heavy metals in soil. Once present in the soil, the heavy metals are persistent. Soils are intensively cropped to meet the increasing demand for food production. Due to high cost and scarcity of chemical fertilizers, the land disposal of agricultural, municipal wastes is widely practiced as a major and economic source of nutrients and organic matter for growing cereal crops by poor farmers. Growing cereal crops on widespread unregulated waste amended agricultural soils may become a food security problem because toxic concentration of heavy metals may accumulate in the food chain or cause failure of crops. In addition, crops which have the ability to tolerate may accumulate greater concentration of heavy metals and become environmental and public health issues [17].

Principally, the food chain (soil-plant-human) pathway is recognized as one of major pathways for human exposure to soil contamination. Soil-to-plant transfer is one of the key components of human exposure to metals through the food chain. The poisoning effects of heavy metals are due to their interference with the normal body bio chemistry in the normal metabolic processes. When ingested, in the acid medium of the stomach, they are converted to their stable oxidation states $\left(\mathrm{Zn}^{2+}, \mathrm{Pb}^{2+}, \mathrm{Cd}^{2+}\right.$ and $\mathrm{Ba}^{2+)}$ and combine with the body's biomolecules such as proteins and enzymes to form strong and stable chemical bonds.[8, 18].

\subsection{Chemical Composition and modes of consumption of barley}

Barley grain is rich in starch and sugars relatively poor in protein and very low in fat. The husk is mostly composed of Legnin, Pentosans, Mannan, Uronic acids, Hemicelluloses and Cellulose Fiber. Silica is present in the outer walls of the husk and the awns contain large amounts of silica. Polyphenols which may complex with proteins are abundant in the paricarp, testa and aleuroue layre. The strategy endosperm is composed of about 85 $89 \%$ starch enclosed in cell walls. B-Glu-Can makes up $75 \%$ of the cell wall, and the rust arabinoxylanes. The embryo consists of about $7 \%$ cellulose, $14-17 \%$ lipids, $14-15 \%$ sucrose $5-10$ ash and 34\% proteins. The ash content of barley $(2-3 \%)$ is influenced by the growing season, soil zone, and soil type and soil fertility. The distribution of minerals is uneven throughout the kernel and the rachis (5-14\%) and awns (17-38\%) contain large portion of the minerals. The ash content of barley ranges from 2.2 to $3.9 \%$ [19].

In recent years barley is gaining renewed interest as a food component because of its high soluble dietary fiber and $\beta$-glucan content compared with other cereals. Barley grain contains about $20 \%$ of dietary fiber, $\beta$ glucan, is an important dietary fiber in barley, varies between 3 and $7 \%$ have shown that a significant blood cholesterol lowering effects. Moreover, barley $\beta$-glucan increases the viscosity of digestion in the intestine, slowing down the rate of starch digestion and absorption, which is beneficial to diabetics. There is, however, a large variation in the chemical composition between different barley types. Hull-less barley contains less ash and dietary fiber and more starch, protein and fat than covered barley [20].

\subsection{Health benefits of essential and toxic metals}

The importance of mineral elements in human, animal and plant nutrition has been well recognized. Deficiencies or disturbances in the nutrition of an animal cause a variety of diseases and can arise in several ways. When a trace element is deficient, a characteristic syndrome is produced which reflects the specific functions of the nutrient in the metabolism of the animal. The trace elements are essential components of enzyme systems. Simple or conditioned deficiencies of mineral elements therefore have profound effects on metabolism and tissue structure. To assess the dietary intake and adequacy of minerals, information needs to be collected on mineral element content of foods; diets and water. Grazing livestock from tropical countries often do not receive mineral supplementation except for common salt and must depend almost exclusively upon forage for their mineral requirements [8, 21-29].

\section{Materials and method}

\subsection{Instrumentation}

The following are list of the major apparatus used during the experiments in this study: Plastic sample holders, hot electric plate, Pipettes, safety goggles. Ceramic pestle and mortar were used for grinding different verities of barley grain; digital analytical balance (Mettler Toledo, Model AT250, and Switzerland) and oven (J. P. select, Spain) were used for weighing and drying the samples respectively. Quick-fit round bottom flasks $(500 \mathrm{~mL})$ were used to digest the samples. BUCK SCIENTIFIC MODEL 210VGP (EAST NORWALK, USA) atomic 
absorption spectrophotometer equipped with deuterium ark back ground correctors was used for analysis of the analyte metals using air- $\mathrm{C}_{2} \mathrm{H}_{2}$ flame.

\subsection{Reagents and Standard Solutions}

Chemicals and reagents that were used in the analysis are all analytical grade concentrated $(65-70 \%) \mathrm{HNO}_{3}$ (unichem ${ }^{\circledR}$ chemical reagents, India) and $30 \% \mathrm{H}_{2} \mathrm{O}_{2}$ (unichem ${ }^{\circledR}$ chemical reagents, India) were used for digestion of barley samples. Stock standard solutions of the metals, $1000 \mathrm{mg} / \mathrm{l}(\mathrm{K}, \mathrm{Ca}, \mathrm{Mg}, \mathrm{Zn}, \mathrm{Mn}, \mathrm{Cu}, \mathrm{Co}, \mathrm{Ni}$, $\mathrm{Cr}, \mathrm{Pb}$, and $\mathrm{Cd}), \mathrm{LaCl}_{3} \cdot 7 \mathrm{H}_{2} \mathrm{O}$ solution used to reduce chemical interference of magnesium and calcium, deionized water was used for preparation of standard solutions, dilution and for cleaning (rinsing) purpose.

\subsection{Procedures}

\subsubsection{Study site}

The study was carried out in Aleta wondo woreda which is located between $6^{0} 15^{\prime}-6^{0} 45^{\prime} \mathrm{N}$ latitude and between $38^{0} 15^{\prime}-38^{0} 45^{\prime} \mathrm{E}$ longitude; and Dale Woreda which is located between $6^{\circ} 27^{\prime} 00^{\prime \prime}-6^{\circ} 51^{\prime} 00^{\prime \prime} \mathrm{N}$ latitude and $38^{\circ} 00^{\prime} 00^{\prime \prime}-38^{\circ} 37^{\prime} 00^{\prime \prime E}$ longitude in Sidama zone of southern nations nationalities and peoples region (SNNPRG).The study areas experience bimodal rainfall pattern with the long rain season (about $75 \%$ of the total annual rainfall) extending from mid-May to September and the short rain season (about $25 \%$ of the total annual rainfall) extending from February to mid-April. The elevation of Aleta wondo wereda ranges between 1001 and 2500 meters above sea level. This rain fall regime is characterized by one of the rainy season, i.e. the rainy months from March to October. The Woreda receive a mean annual rainfall varying from $801-1000 \mathrm{~mm}$ in the western parts to $1401-1600 \mathrm{~mm}$ in the central and northern parts; Whereas Dale woreda lies in the altitude range of $1100 \mathrm{~m}$ to $3200 \mathrm{~m}$ (from low lands in the west to the highlands in the east). The maximum rainfall and temperature is $1448 \mathrm{~mm}$ and $29 \mathrm{C}^{\circ}$, respectively $[30,31,32]$.

\subsubsection{Methodology of sampling.}

Primarily the sampling stations assessed for two days to select the appropriate Sampling sites, and number of sample sites. Three sample sites in Dale wereda, where the barley verities grown investigated. Four different barley varieties collected from the market in the sample sites in Dale wereda and randomly in Aleta wendo wereda. Then the barley varieties (i.e. Senef, Bera, Nech, and Semereta) which were harvested at maturity stage randomly collected to make representative samples of each barley variety which were prepared by composing the samples taken from five different sellers. All barley samples were collected in March 2011 primarily from different sellers in two local markets, Aleta wondo and in Dale woredas. The samples collected with the help of plastic bags to avoid contamination of the sample with any of the element being studied. The experiment was conducted at Hawassa university chemistry department laboratory class.

\subsubsection{Cleaning Procedures of Equipments}

All glassware containers; including sample bottles, flasks, pipettes, Digestion flask were washed in the following sequence; 1:1 nitric acid, tap water, detergent, tap water, and reagent water and dried in oven and kept in dust free place until analysis begins [33].

\subsubsection{Analysis of mineral content by the wet digestion method.}

Many materials of interest such as soils plants tissues, and animal tissues are not directly soluble in common solvents , and extensive preliminary treatment is required to obtain a solution of the analyte in a form ready for atomization. Decomposition of materials usually required rigorous treatment of the sample at high temperature with a concomitant potential for loss of the analyte by volatilization or as a particulate in the smoke. Furthermore the reagents used in decomposing a sample often introduce the kinds of chemical and spectral interferences. Some of the common methods used for decomposing and dissolving samples for atomic absorption methods include treatment with hot mineral acids: oxidation with liquid reagents such as sulfuric, nitric or per chloric acids [34].

Organic matter can be decomposed by dry ashing in a muffle furnace at high temperature. However losses due to volatilization and incorporation in some solid material either in the ash residue or in the ashing vessel can be quite serious with dry ashing. Wet ashing is more reliable preparation technique before measurements by atomic absorption, however there is still the possibility of spray losses at time of transfer of the digest to volumetric flasks for dilution [35].

In high-silica containing plant tissues (like wheat, barley, rice, sugarcane, etc.) full recovery of micronutrient cations $(\mathrm{Zn}, \mathrm{Cd}, \mathrm{Pb}$, and $\mathrm{Cu})$ is not possible by dry ashing procedure. Therefore, this kind of plant materials should be wet-digested using nitric acid Reuter and Robinson $(1986,1997)$ and Jones et al. (1991). Wet digestion involves the destruction of organic matter through the use of both heat and acids. Acids that have been used in these procedures include $\mathrm{H}_{2} \mathrm{SO} 4, \mathrm{HNO}_{3}$, and $\mathrm{HClO}_{4}$, either alone or in combination. Hydrogen peroxide $\left(\mathrm{H}_{2} \mathrm{O}_{2}\right)$ is also used to enhance reaction speed and complete digestion. Most laboratories have eliminated the use of $\mathrm{HClO}_{4}$ due to risk of explosion. Safety regulations require specially designed hoods where $\mathrm{HClO}_{4}$ is utilized. Hot plates or digestion blocks are utilized to maintain temperatures of 80 to $125^{\circ} \mathrm{C}$. After 
digestion is complete and the sample is cooled, the vessel is filled to volume and dilutions are made to meet analytical requirements [36].

Nitric acid digestion results in dissolution of many common metals and is especially useful for oxidation of organic matter. Nitric acid is manufactured in very pure form with a very low content of trace element. Furthermore, nitric acid is the acid of choice considering the low interference effect in respect to many subsequent analytical methods. This makes it very suitable for analytical chemistry purposes. Due to the strong oxidising effect and low interference effect in the subsequent analysis, it is commonly used for digestion of solid samples. Like aqua regia, especially silicate matrix will not be totally solubilized. The fraction dissolved may be described as the "nitric acid soluble portion" of elements in a given matrix [3, 37].

The mineral concentrations of cereal grains and flours can be determined by atomic absorption without appreciable spectral interferences and with only minor chemical interferences [38]. Many other elements (like, $\mathrm{K}, \mathrm{Ca}, \mathrm{Mg}, \mathrm{Na}$ ) can also be determined in the same digest. Calcium, magnesium, iron, zinc, and manganese contents can be determined through atomic absorption spectrophotometry. Lanthanum was added to calcium and magnesium samples to prevent interferences caused by phosphate ions. Potassium and sodium were determined through atomic emission spectrophotometry (AOAC, 1990).

\subsubsection{Application and principle of atomic absorption spectrometry.}

Metals in solution may be readily determined by flame (direct aspiration) atomic absorption spectrophotometer. The method is simple, rapid, and applicable to a large number of environmental samples including, but not limited to, ground water, aqueous samples, extracts, industrial wastes, soils, sludge's, sediments, and similar wastes. With the exception of the analyses for dissolved constituents, all samples require digestion prior to analysis. Analysis for dissolved elements does not require digestion if the sample has been filtered and then acidified.

The principle for FAAS based on a light beam from a hollow cathode lamp is directed through the flame into a monochromator, and onto a detector that measures the amount of absorbed light. Absorption depends upon the presence of free unexcited ground-state atoms in the flame. Because the wavelength of the light beam is characteristic of only the metal being determined, the light energy absorbed by the flame is a measure of the concentration of that metal in the sample. Solvents, reagents, glassware, and other sample processing hardware may yield artifacts and/or interferences to sample analysis. All of these materials must be demonstrated to be free from interferences under the conditions of the analysis by analyzing method blanks.

In atomic absorption spectroscopy, measurement is made of the radiation absorbed by the non excited atoms in the vapor state. In emission spectroscopy, measurement is made of energy emitted when atoms in the excited state return to the ground state. Energy of characteristic wavelengths (resonance lines) and are raised to a higher energy state. The radiation not removed by absorption is isolated by a monochrometer and detected by a photomultiplier $[33,39]$.

Table2. Operational parameters during determination of metallic elements.

\begin{tabular}{|l|l|l|l|l|l|l|}
\hline Element & Wavelength $(\mathrm{nm})$ & Current(mA) & Slit width(nm) & Sample energy & IDL(mg/L) & Oxidant-Fuel \\
\hline $\mathrm{K}$ & 766.5 & 2.0 & 0.7 & - & 0.010 & Air- $\mathrm{C}_{2} \mathrm{H}_{2}$ \\
\hline $\mathrm{Mg}$ & 385.2 & 1.0 & 0.7 & 3.889 & 0.010 & Air- $\mathrm{C}_{2} \mathrm{H}_{2}$ \\
\hline $\mathrm{Ca}$ & 422.7 & 2.0 & 0.7 & 3.896 & 0.001 & Air $-\mathrm{C}_{2} \mathrm{H}_{2}$ \\
\hline $\mathrm{Zn}$ & 213.9 & 2.0 & 0.7 & 2.999 & 0.050 & Air- $\mathrm{C}_{2} \mathrm{H}_{2}$ \\
\hline $\mathrm{Mn}$ & 279.5 & 3.0 & 0.7 & 3.904 & 0.001 & Air- $\mathrm{C}_{2} \mathrm{H}_{2}$ \\
\hline $\mathrm{Cu}$ & 324.7 & 2.0 & 0.7 & 3.891 & 0.005 & Air- $\mathrm{C}_{2} \mathrm{H}_{2}$ \\
\hline $\mathrm{Ni}$ & 232 & 7.0 & 0.2 & 2.616 & 0.100 & Air- $\mathrm{C}_{2} \mathrm{H}_{2}$ \\
\hline $\mathrm{Co}$ & 240.7 & 4.5 & 0.2 & 2.110 & 0.050 & Air- $\mathrm{C}_{2} \mathrm{H}_{2}$ \\
\hline $\mathrm{Cr}$ & 357.9 & 2.0 & 0.7 & 3.557 & 0.050 & Air- $\mathrm{C}_{2} \mathrm{H}_{2}$ \\
\hline $\mathrm{Pb}$ & 217.0 & 3.0 & 0.7 & 2.438 & 0.100 & Air- $\mathrm{C}_{2} \mathrm{H}_{2}$ \\
\hline $\mathrm{Cd}$ & 228.9 & 2.0 & 0.7 & 3.254 & 0.010 & Air- $\mathrm{C}_{2} \mathrm{H}_{2}$ \\
\hline
\end{tabular}

\subsubsection{Analytical Procedure}

All four barley (Senef, Bera, Nech and Semereta) varieties were dried at $105{ }^{\circ} \mathrm{C}$ in oven till constant weight. Replicate $2 \mathrm{~g}$ of each barley cultivar were weighed in to $100 \mathrm{ml}$ conical flasks and treated with $5 \mathrm{ml}$ of nitric acid. $5 \mathrm{ml}$ of nitric acid was also added to empty conical flask serving as a blank. The flasks were covered with watch glasses, and their contents were heated to reflux gently on an electric plate. After refluxing for one hour the contents of flasks were treated with $5 \mathrm{ml}$ more of nitric, $3 \mathrm{ml}$ of $30 \%$ hydrogen peroxide was added, and heating at gentle reflux was continued for another hour. The reflux removed from the flasks, and the heating was continued until the volumes of their contents were reduced to $2-3 \mathrm{ml}$. The contents of flasks were cooled, diluted with high purity water, and filtered through Whatman \# 42 paper in to $25 \mathrm{ml}$ volumetric flasks. The contents of the flasks were brought to volume with high purity water and examined by atomic absorption spectrometry for their potassium, calcium, magnesium, copper, zinc, nickel, chromium, cobalt, lead and cadmium levels. Total mineral 
content was determined by the wet digestion method. The above-mentioned analyses were performed according to the standard Official Methods of Analysis of the Association of Official Analytical Chemists [FNB 1989, AOAC 1995]. Total insoluble minerals were determined using Flame Atomic Absorption Spectro-photometer (FAAS), according to Approved Methods of the American Association of Cereal Chemists [AACC 2000].

\subsubsection{Digestion of barley samples spiked with standard metals solutions}

For the determination of the efficiency of the developed optimized digestion procedure used for the analysis, barley samples Spiked at once with a known amount of respective metal analyte to bring the concentration of the analyte to 2 to 5 times the original concentration. But if all of the samples in the batch have analyte concentrations below the detection limit, spike the selected sample at 20 times the detection limit [40].

Fixed volumes of standard solutions of the metals were added from $500 \mathrm{mg} / \mathrm{L}$ standard solution of the corresponding metals ( $\mathrm{Ca}, \mathrm{Mg}$ and $\mathrm{K}$ ). However, for $\mathrm{Zn}, \mathrm{Mn}, \mathrm{Co}, \mathrm{Cu}, \mathrm{Ni}, \mathrm{Pb}$ and $\mathrm{Cd}$ the added volume was taken from $10 \mathrm{mg} / \mathrm{L}$ of its standard solution. Each respective was taken, so that after digestion to be diluted to $25 \mathrm{ml}$. Then, they were digested in the same procedure and diluted to $25 \mathrm{~mL}$ volumetric flask based on the procedure of the developed digestion method for barley.

\section{Result and discussion}

\subsection{Sample preparation technique of barley samples}

The procedure adopted to obtain as representative a sample as possible will depend on the type of solid. This process is of great importance since, if it is not satisfactory done, the labor and time spent in making a careful analysis of the sample may be completely wasted. If the material is more or less homogeneous, sampling is comparatively simple. For the most part, bulk materials are non homogeneous, e.g. Minerals, sediments and food stuffs. They may contain particles of different composition which are not uniformly distributed within the material. In sampling of this case a number of increments are taken in random manner from points in the bulk material, so that each part has an equal chance of being selected. The combination of these increments then forms the growth sample. The gross sample is often too large for direct analysis and must be divided further to produce a sub sample [41].

The size of the sample must be adequate, depending upon what is being measured, the type of measurement being made, and the level of contaminants. Even starting with a well-gathered sample, errors can occur in two distinct ways. First, errors in splitting the sample can result in bias with concentration of one or more of the components in either the laboratory sample or the discard material. Second, the process of attrition used in reducing particle sizes will almost certainly create contamination of the sample. In this study all five increments for each barley samples were dried at $105^{\circ} \mathrm{c}$ in oven till constant weight for two days, then grounded using mortar and pestle in such a way that the size to pass in 0.5-1 mm mesh [36, 42]. Then equal amount of five sub samples for each were mixed using mesh, so that the growth sample to be more or less homogeneous and kept in poly ethylene bag until digestion.

\subsection{Optimization of analytical procedure}

One of the basic requirements for sample preparation for the analysis is to get an optimum condition for digestion. The optimum condition is the one which leads to Minimum reagent volume consumptions, Minimum digestion time, Minimum residue (clear solution) \& Easy of simplicity. In order to develop an optimum procedure for the analysis of samples, different digestion parameters were tasted and the procedures that produce white pure residue, consumed minimal reagent volumes was selected from the different alternatives. G. Q. Shar, L. A. Shar [3], selected the optimized procedure involving $5 \mathrm{~mL}$ of $70 \% \mathrm{HNO}_{3}$ and $2 \mathrm{~mL}$ of $35 \% \mathrm{H}_{2} \mathrm{O}_{2}$ for digestion time of more than 2 hours. Having this as a base, this procedure was checked using different digestion parameters. The optimal procedure chosen on the basis of these criteria required $3.5 \mathrm{~h}$ for complete digestion of $2 \mathrm{~g}$ dried barley sample with $10 \mathrm{~mL}$ of $65-68 \% \mathrm{HNO}_{3}$ and $3 \mathrm{~mL}$ of $30 \% \mathrm{H}_{2} \mathrm{O}_{2}$ as given below [43].

Table 3. Result of optimized procedure for barley sample digestion.

\begin{tabular}{|c|c|c|c|c|c|c|}
\hline Procedure & $\begin{array}{l}\text { Sample } \\
\text { Mass }\end{array}$ & $\begin{array}{l}\text { Reagent } \\
\text { volume }\end{array}$ & Time duration & Temp/tim & Observation & Remark \\
\hline 1 & $2 \mathrm{gm}$ & $\begin{array}{c}\text { 6ml HNO3, } \\
2 \mathrm{ml} \mathrm{H} 2 \mathrm{O} 2\end{array}$ & Until 2-3 ml remains. & $300 / 3 \mathrm{~h}$ & Oily colour & Rejected \\
\hline 2 & $2 \mathrm{gm}$ & $\begin{array}{c}5 \mathrm{ml} \mathrm{HNO} 3, \\
2 \mathrm{ml} \mathrm{H} 2 \mathrm{O} 2\end{array}$ & Until 2-3 ml remains. & $300 / 2 \mathrm{~h}$ & Deep yellow colour & Rejected \\
\hline 3 & $2 \mathrm{gm}$ & $\begin{array}{l}\text { 10ml HNO3, } \\
2 \mathrm{ml} \mathrm{H} 2 \mathrm{O} 2\end{array}$ & Until 2-3 ml remains. & $390 / 3.5 \mathrm{~h}$ & Clear color less & Accepted \\
\hline 4 & $2 \mathrm{gm}$ & $\begin{array}{l}8 \mathrm{ml} \mathrm{HNO} 3, \\
2 \mathrm{ml} \mathrm{H} 2 \mathrm{O} 2\end{array}$ & Until 2-3 ml remains. & $330 / 3 \mathrm{~h}$ & Pale yellow colour & Rejected \\
\hline 5 & $2 \mathrm{gm}$ & $\begin{array}{l}6 \mathrm{ml} \mathrm{HNO}_{3}, \\
1 \mathrm{ml} \mathrm{H} \mathrm{H}_{2} \mathrm{O}_{2}\end{array}$ & Until 2-3 ml remains. & $360 / 3 h$ & Light yellow & Rejected \\
\hline
\end{tabular}




\subsection{Calibration curves}

In theory, atomic absorption should follow beers law with absorbance being directly proportional to concentration. In fact, departure from linearity is often encountered, and it is unwise to perform an atomic absorption analysis without experimentally determining whether or not a linear relationship does exist. Thus periodically a calibration curve that covers rang of concentration found in the sample should be prepared. The calibration curve is a plot of detector response as a function of concentration. A typical calibration curve is used to determine the amount of analyte in the unknown samples [34, 44]. A series of working standard solutions were prepared from the $10 \mathrm{mg} / \mathrm{L}$ intermediate standard solutions of their respective metals and the solutions were aspirated into the atomizer and absorbance was recorded.

Table 4: Statistical data for standard solutions of elements.

\begin{tabular}{|l|l|l|l|l|}
\hline Elements & $\begin{array}{l}\text { Standard solution in } \\
\mathrm{mg} / \mathrm{L}\end{array}$ & Absorbance & $\begin{array}{l}\text { Régression équation } \\
\mathrm{y}=\mathrm{mx}+\mathrm{c}\end{array}$ & $\begin{array}{l}\text { Correlation } \\
\text { coefficient, } \mathrm{R}^{2}\end{array}$ \\
\hline $\mathrm{K}$ & $0.1,0.5,2,4$ & $3.3556-100.1077$ & $\mathrm{Y}=25.05542 \mathrm{X}+0.59956$ & 0.99956 \\
\hline $\mathrm{Mg}$ & $0.1,0.2,0.3,0.6$ & $0.10325-0.61635$ & $\mathrm{Y}=1.02284 \mathrm{X}+0.00649$ & 0.99951 \\
\hline $\mathrm{Ca}$ & $0.5,1,2,4$ & $0.03304-0.2722$ & $\mathrm{Y}=0.06774 \mathrm{X}+0.00228$ & 0.9997 \\
\hline $\mathrm{Zn}$ & $0.01,0.1,0.5,1$ & $0.00716-0.56311$ & $\mathrm{Y}=0.56159 \mathrm{X}+0.0056$ & 0.99974 \\
\hline $\mathrm{Mn}$ & $0.035,0.5,1,3$ & $0.00296-0.17133$ & $\mathrm{Y}=0.17438 \mathrm{X}-0.00175$ & 0.99961 \\
\hline $\mathrm{Cu}$ & $0.01,0.1,0.3,0.6$ & $0.00278-0.11854$ & $\mathrm{Y}=0.19748 \mathrm{X}+5.27471 \mathrm{E}^{-4}$ & 0.9998 \\
\hline $\mathrm{Ni}$ & $0.06,0.1,0.4,0.6$ & $0.0015-0.0132$ & $\mathrm{Y}=0.02167 \mathrm{X}+1.17324 \mathrm{E}^{-4}$ & 0.99982 \\
\hline $\mathrm{Co}$ & $0.06,0.1,0.4,0.6$ & $0.00109-0.01802$ & $\mathrm{Y}=0.03103 \mathrm{X}-5.29147 \mathrm{E}^{-4}$ & 0.99968 \\
\hline $\mathrm{Cr}$ & $0.05,0.1,0.4,0.8$ & $0.00153-0.03028$ & $\mathrm{Y}=0.03836 \mathrm{X}-3.51133 \mathrm{E}^{-4}$ & 0.99998 \\
\hline $\mathrm{Pb}$ & $0.05,0.1,0.5,1$ & $9.233 \mathrm{E}^{-4}-0.03588$ & $\mathrm{Y}=0.0362 \mathrm{X}-2.39202 \mathrm{E}^{-4}$ & 0.99946 \\
\hline $\mathrm{Cd}$ & $0.02,0.04,0.06,0.1$ & $0.00491-0.02958$ & $\mathrm{Y}=0.3087 \mathrm{X}-0.00108$ & 0.99958 \\
\hline
\end{tabular}
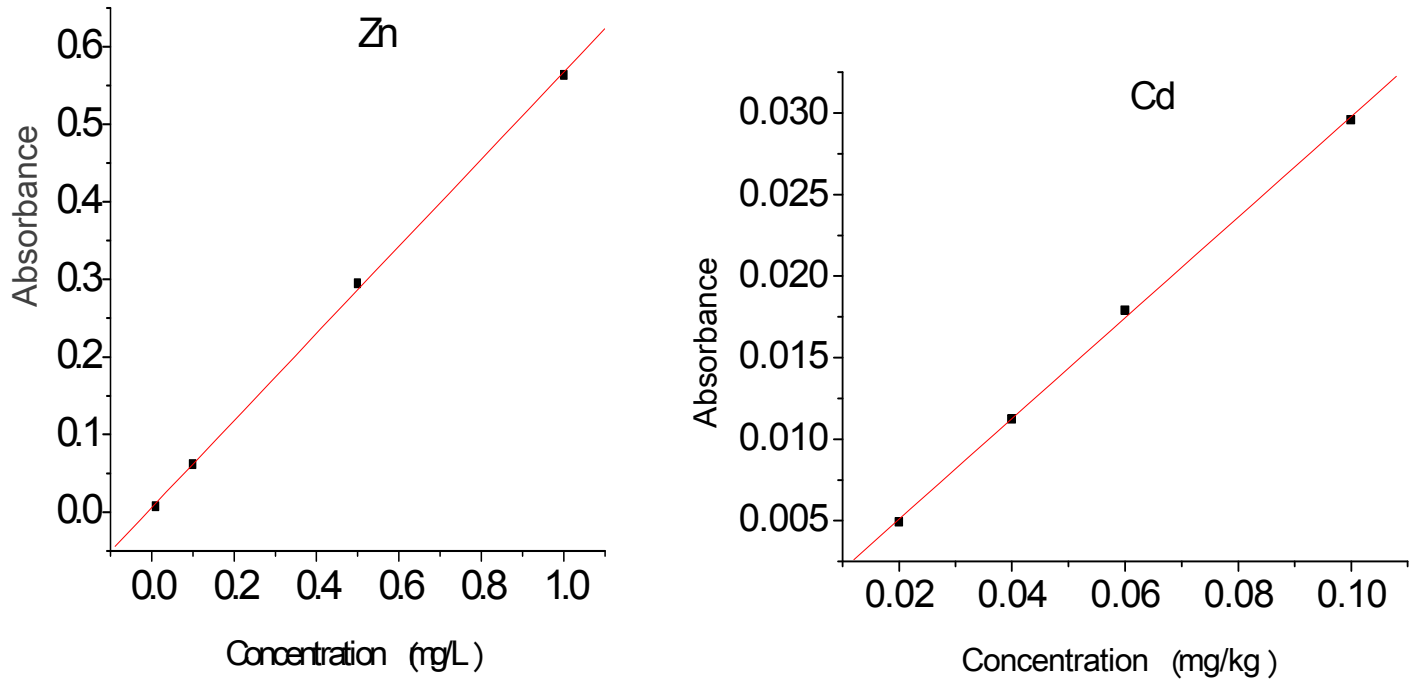

Figure 3. The calibration graphs of $\mathrm{Zn}$ and $\mathrm{Cd}$ for the standard solution of metals.

\subsection{Evaluation of Analytical Results}

4.4.1. Method detection limit (MDL)

MDL is the minimum concentration of a substance that can be measured and reported with $99 \%$ confidence that the analyte concentration is greater than zero and is determined from analysis of a sample in a given matrix containing the analyte. MDL can be calculated as follows: MDL $=\mathrm{t}(\mathrm{n}-1,1-\mu=0.99)(\mathrm{S})$ where, MDL is the method detection limit, $\mathrm{t}(\mathrm{n}-1,1-\mu=0.99)$ is the students $\mathrm{t}$ value appropriate for a $99 \%$ confidence level and a standard deviation estimate with n-1 degrees of freedom, $\mathrm{S}$ is the standard deviation of the replicate analyses of the sample. $\mathrm{S}$ is calculated as:

$$
S=\frac{1}{\mathrm{n}-1}\left[\sum_{n=1}^{n}\left(x_{i}^{2}\right)-\frac{\left(\sum_{\mathrm{n}=1}^{\mathrm{n}} \mathrm{x}_{\mathrm{i}}\right)^{2}}{\mathrm{n}}\right]
$$


The measured level of the analyte obtained is in the recommended range of one to five times the estimated detection limit, then seven aliquots of the sample to be used to calculate the method detection limit was taken and processed through the entire analytical method. As can be seen from the table, the MDL values are greater than the IDL, MDLX10 $>$ spike, MDL $<$ spike and has acceptable \% recovery hence, the result of the analysis could be reliable [45]. The results are given in Table 5 .

\subsubsection{Instrumental detection limit and limit of quantitation}

Instrumental detection limit (IDL): is the lowest concentration that can be detected by an instrument without correction for the effect of sample matrix or method specific parameters such as sample preparation. Instrument detection limits (IDLs) are a useful tool to evaluate the instrument noise level and response changes over time for each analyt from a series of reagent blank analyses to obtain a calculated concentration. The instrument detection limits (IDL) is the lowest detectable amount of each analyte that the instrument can detect and record. The IDL was computed using the method described by Miller and Miller (1998).IDL = 3Sb/b, where: $b=$ the slop of the graph, $S b=$ standard error of the regression line.

Limit of Quantitation (LOQ): This is the level above which quantitative results may be obtained with a specified degree of confidence. The LOQ is mathematically defined as equal to 10 times the standard deviation of the results for a series of replicates used to determine a justifiable limit of detection. Limits of quantization are matrix, method, and analyte specific. The limits of quantification (LOQ) calculated from the expressions LOQ = $10 \mathrm{Sb} / \mathrm{b}$, where $\mathrm{Sb}$ is the standard deviation of the blank and $\mathrm{b}$ is the slope of the analytical curve $[45,46,47,48]$. Table 5: Method detection, instrumental detection and Quantization limit in $\mathrm{mg} / \mathrm{L}$ ) for all metals determined in barley samples.

\begin{tabular}{|l|l|l|l|}
\hline Metals & MDL $(\mathrm{mg} / \mathrm{L})$ & IDL $(\mathrm{mg} / \mathrm{L})$ & LOQ $(\mathrm{mg} / \mathrm{L})$ \\
\hline $\mathrm{K}$ & 0.12731 & 0.010 & 0.472 \\
\hline $\mathrm{Ca}$ & 0.07050 & 0.010 & 0.400 \\
\hline $\mathrm{Mg}$ & 0.00367 & 0.001 & 0.078 \\
\hline $\mathrm{Zn}$ & 0.00059 & 0.050 & 0.091 \\
\hline $\mathrm{Mn}$ & 0.00012 & 0.001 & 0.179 \\
\hline $\mathrm{Cu}$ & 0.00011 & 0.005 & 0.048 \\
\hline $\mathrm{Ni}$ & 0.00124 & 0.100 & 0.050 \\
\hline $\mathrm{Cr}$ & 0.00462 & 0.050 & 0.047 \\
\hline $\mathrm{Co}$ & 0.00218 & 0.050 & 0.065 \\
\hline $\mathrm{Pb}$ & 0.00584 & 0.100 & 0.131 \\
\hline $\mathrm{Cd}$ & 0.0000002 & 0.010 & 0.013 \\
\hline
\end{tabular}

If the level of analyte in the sample was below the determined MDL or exceeds 10 times the MDL of the analyte in reagent water, the value for the MDL will not be reported.

\subsubsection{Recovery test for the optimized procedure}

The efficiency of the method was assessed by spiking the barley samples with known amounts of metals, and each of the metals were analyzed in triplicate. For the purpose of comparison, measurement by an established method or by an accredited institution is accepted as the true value (R. Brukh, 2003). But since there was no standard reference barley varieties in the laboratory, spiking experiments were employed to validate the digestion procedure in terms of using lower level of traceability, recovery test $(\mathrm{R})$ as follows.

$$
\begin{aligned}
& \% \mathrm{R}=(\mathrm{Cs}-\mathrm{C}) / \mathrm{S} * 100 \\
& \mathrm{R}=\text { percent recovery } \\
& \mathrm{Cs}=\text { fortified sample concentration } \\
& \mathrm{C}=\text { sample back ground concentration } \\
& \mathrm{S}=\text { concentration added to fortify the sample }
\end{aligned}
$$

The recoveries of the metals in the spiked barley sample are between 96 to $111(\% \mathrm{R} \pm \mathrm{SD})$. There for the laboratory performance for each analyt falls in the required control limits of $85-115 \%$ lead, which has $78 \%$ recovery. Thus, the digestion procedure is believed to remove metal fractions associated with organic matter [EPA, 1992 method 2007A, revision 1] 
Table 6: Analytical results for Recovery test of the optimized procedure for barley sample.

\begin{tabular}{|l|l|l|l|l|}
\hline Metal & $\begin{array}{l}\text { Concentration in sample } \\
(\mathrm{mg} / \mathrm{L})\end{array}$ & $\begin{array}{l}\text { Amount } \\
(\mathrm{mg} / \mathrm{L})\end{array}$ & Added & $\begin{array}{l}\text { Concentration } \\
(\mathrm{mg} / \mathrm{L})^{\mathrm{a}}\end{array}$ \\
\hline $\mathrm{K}$ & 340.38 & 350 & 377.07 & 98.2 \\
\hline $\mathrm{Ca}$ & 94.49 & 280 & 366.60 & 97.3 \\
\hline $\mathrm{Mg}$ & 42.30 & 130 & 171.16 & 99.6 \\
\hline $\mathrm{Zn}$ & 3.56 & 10.68 & 13.82 & 96 \\
\hline $\mathrm{Mn}$ & 0.93 & 2.79 & 3.860 & 105 \\
\hline $\mathrm{Cu}$ & 0.50 & 1.50 & 1.95 & 97 \\
\hline $\mathrm{Co}$ & 0.50 & 1.50 & 1.78 & 86 \\
\hline $\mathrm{Ni}$ & 0.136 & 0.41 & 0.499 & 89 \\
\hline $\mathrm{Cr}$ & 0.062 & 0.186 & 0.260 & 109 \\
\hline $\mathrm{Pb}$ & 0.073 & 0.22 & 0.266 & 88 \\
\hline $\mathrm{Cd}$ & 0.066 & 0.198 & 0.285 & 111 \\
\hline
\end{tabular}

${ }^{\mathrm{a}}$ Values are mean of triplicate readings of triplicate analyses.

balus are mean of triplicate percentage recovery values of triplicate analyses

\subsection{Determination of essential and non essential metals.}

Barley is a major source of carbohydrate, calcium and iron. Moreover, it constitutes these essential mineral nutrients (Table 9). The nutrient content of barley (Table 1) shown below. For potassium and magnesium determination the digested samples were diluted to $100 \mathrm{ml}$ with deionized water before analysis, but, to $55 \mathrm{ml}$ for calcium. Table 7; mean $\pm(\mathrm{Sd}, \mathrm{n}=3)$ and ranges of essential metals in sidama barley varieties (Hordeum Vulgare L.) s grown in Dale wereda.

\begin{tabular}{|c|c|c|c|c|c|}
\hline Species & \multicolumn{5}{|c|}{ Metals concentration $(\mathrm{mg} / \mathrm{kg})$ in Dale wereda*. } \\
\hline Metals & $\mathrm{K}$ & $\mathrm{Ca}$ & $\mathrm{Mg}$ & $\mathrm{Zn}$ & $\mathrm{Mn}$ \\
\hline Semereta & $4434.86 \pm 176.92$ & $1032.37 \pm 137.29$ & $757,57 \pm 36.43$ & $68.66 \pm 4.95$ & $17.91 \pm 1.06$ \\
\hline Nech & $2959.25 \pm 252.28$ & $1347.48 \pm 483.19$ & $727 \pm 80.54$ & $80.54 \pm 8.66$ & $11.88 \pm 0.95$ \\
\hline Senef & $3561.95 \pm 176.92$ & $740.38 \pm 85.06$ & $723.55 \pm 38.69$ & $63.29 \pm 14.52$ & $11.00 \pm 0.85$ \\
\hline Bera & $4254.82 \pm 299.96$ & $1181.22 \pm 77.52$ & $528.71 \pm 43.06$ & $44.55 \pm 23.85$ & $12.42 \pm 0,94$ \\
\hline \multicolumn{6}{|c|}{ Metals concentration $(\mathrm{mg} / \mathrm{kg})$ in Aleta wendo wereda*. } \\
\hline Semereta & $3390.38 \pm 56.55$ & $1047.59 \pm 50.24$ & $624.83 \pm 5.39$ & $46.41 \pm 4.72$ & $20.35 \pm 0.42$ \\
\hline Nech & $2954.72 \pm 230.28$ & $1238.74 \pm 155.03$ & $586.74 \pm 38.34$ & $64.21 \pm 10.86$ & $17.66 \pm 0.74$ \\
\hline Senef & $3567.49 \pm 100.04$ & $897.04 \pm 41.02$ & $628.64 \pm 31.43$ & $56.78 \pm 11.47$ & $17.48 \pm 0.65$ \\
\hline Bera & $3981.15 \pm 122.01$ & $1015.59 \pm 81.60$ & $669.62 \pm 33.76$ & $82.39 \pm 5.95$ & $11.63 \pm 1.05$ \\
\hline
\end{tabular}

Table 8; mean $\pm(\mathrm{Sd}, \mathrm{n}=3)$ and ranges of essential and non essential metals in Sidama barley varieties (Hordeum Vulgare L.) s grown in Aleta wondo wereda.

\begin{tabular}{|l|l|l|l|l|l|l|}
\hline Species & Metals concentration $(\mathrm{mg} / \mathrm{kg})$ & in Dale wereda, $\mathrm{X}^{*}$ & $\mathrm{Cd}$ \\
\hline & $\mathrm{Cu}$ & $\mathrm{Co}$ & $\mathrm{Ni}$ & $\mathrm{Cr}$ & $\mathrm{Pb}$ & $\mathrm{Cd}$ \\
\hline Semereta & $4.88 \pm 0.28$ & $0.73 \pm 0.18$ & $1.43 \pm 3.30$ & $0.77 \pm 0.00$ & $1.05 \pm 0.238$ & $0.35 \pm 0.06$ \\
\hline Nech & $4.32 \pm 0.66$ & $1.15 \pm 0.23$ & $1.72 \pm 0.20$ & $0.80 \pm 0.06$ & $0.66 \pm 0.19$ & $0.96 \pm 0.08$ \\
\hline Senef & $6.62 \pm 0.68$ & $1.28 \pm 0.23$ & $1.43 \pm 0.30$ & $0.83 \pm 0.05$ & $1.05 \pm 0.237$ & $0.89 \pm 0.03$ \\
\hline Bera & $6.25 \pm 0.32$ & $6.25 \pm 0.32$ & $1.72 \pm 0.21$ & $0.78 \pm 0.25$ & $0.91 \pm 0.24$ & $0.83 \pm 0.10$ \\
\hline Metals concentration (mg/kg) in Aleta wendo wereda, $\mathrm{X}^{*}$ \\
\hline Semereta & $6.23 \pm 0.53$ & $1.06 \pm 0.07$ & $1.26 \pm 0.24$ & $0.80 \pm 0.06$ & $1.23 \pm 0.40$ & $0.20 \pm 0.04$ \\
\hline Nech & $3.90 \pm 1.08$ & $2.23 \pm 0.40$ & $1.07 \pm 0.10$ & $0.66 \pm 0.18$ & $0.43 \pm 0.00$ & $1.18 \pm 0.08$ \\
\hline Senef & $6.88 \pm 0.52$ & $0.75 \pm 0.23$ & $1.86 \pm 0.33$ & $1.12 \pm 0.53$ & $1.14 \pm 0.34$ & $0.69 \pm 0.11$ \\
\hline Bera & $3.72 \pm 0.02$ & $0.75 \pm 0.23$ & $1.31 \pm 0.31$ & $0.77 \pm 0.00$ & $0.54 \pm 0.19$ & $0.58 \pm 0.06$ \\
\hline
\end{tabular}

$\mathrm{X}^{*}$ is the mean value of the triplicate analysis with triplicate readings of each Sample.

4.5.1. Distribution of selected metals in barley

The distributions of selected metals concentrations in the barley samples are given in Table 7 and 8 . The concentration of the metals (in $\mathrm{mg} / \mathrm{kg}$ ) in the samples are: $\mathrm{K}(2954.72-4434.84)$, Ca $(740.38-1347.48), \mathrm{Mg}$ (483.19 - 757.57) Zn (44.55 - 82.39) Mn (11.00 - 20.35) Cu (3.72 - 6.88) Co (0.75 - 3.03) Ni, (1.305 - 1.86) Cr (0.66 - 1.12), Pb (0.43 -1.23, Cd (0.204 - 1.18).

\section{Variation within the geographical area}

When considering the two woredas the geographical location is not as such different and as a result of this there might be some expectation on which the sites would be able to have identical comparison parameters like 
weather conditions. Generally, among the metals which were determined using the optimized method almost more than $43 \%$ of them are found in higher concentration and $50 \%$ of them are lower in Aleta wondo wereda relative to Dale. $\mathrm{Mn}$ and $\mathrm{Zn}$ concentration being higher in aleta wendo wereda, most probably signify that as there is low rain fall in the region.

\section{Variation along with different barley species}

when we compare different species in both weredas, Semereta gebse varities in Dale wereda has higher in $\mathrm{K}$ and $\mathrm{Mg}$ while lower in $\mathrm{Co}$; and Bera gebse is next to Semereta in $\mathrm{K}$ and lower in $\mathrm{Zn}$ and relatively low in Cr. Senef gebse has also lower concentration of $\mathrm{Ca}$ and $\mathrm{Mn}$, while relatively high concentration of $\mathrm{Cu}, \mathrm{Cr}$ and $\mathrm{Pb}$; but $\mathrm{Nech}$ gebse has higher content of $\mathrm{Ca}$ and high $\mathrm{Cr}$ and lower in $\mathrm{Mg}$; but low in $\mathrm{K}, \mathrm{Cu}$ and $\mathrm{Pb}$. However, when we see the barley species in Aleta wondo weredas Nech gebse has higher in $\mathrm{Cd}$ and lower in $\mathrm{K}, \mathrm{Cr}, \mathrm{Pb}$ and relatively high content of $\mathrm{Ca}$, while Senef is lower in $\mathrm{Co}$ and higher in $\mathrm{Cu}, \mathrm{Ni}, \mathrm{Cr}$ and relatively high content of $\mathrm{Pb}$. Similarly, Bera gebse is lower in $\mathrm{Cu}, \mathrm{Co}, \mathrm{Ni}$ and higher in $\mathrm{Zn}$ when compared with different varieties of barley in the two weredas [figure6].

The pattern of concentration of elements in the different varieties of barley studied decreases in the following order: $\mathrm{K}>\mathrm{Ca}>\mathrm{Mg}>\mathrm{Zn}>\mathrm{Mn}>\mathrm{Cu}$ for all barley species in all wereda. but $\mathrm{Cu}>\mathrm{Ni}>\mathrm{Pb}>\mathrm{Cr}>\mathrm{Co}>$ $\mathrm{Cd}$ for Semereta barley in Dale and $\mathrm{Cu}>\mathrm{Ni}>\mathrm{Pb}>\mathrm{Co}>\mathrm{Cr}>\mathrm{Cd}$ in Alta wendo, for Nech barley $\mathrm{Cu}>\mathrm{Ni}>$ $\mathrm{Co}>\mathrm{Cd}>\mathrm{Cr}>\mathrm{Pb}$ in Dale and $\mathrm{Cu}>\mathrm{Co}>\mathrm{Cd}>\mathrm{Ni}>\mathrm{Cr}>\mathrm{Pb}>$ in Aleta wendo, for Senef barley, $\mathrm{Cu}>\mathrm{Ni}>$ $\mathrm{Co}>\mathrm{Pb}>\mathrm{Cd}>\mathrm{Cr}$ in Dale and $\mathrm{Cu}>\mathrm{Ni}>\mathrm{Pb}>\mathrm{Cr}>\mathrm{Co}>\mathrm{Cd}$ in Aleta wendo, for Bera barley $\mathrm{Cu}>\mathrm{Co}>\mathrm{Ni}>$ $\mathrm{Pb}>\mathrm{Cd}>\mathrm{Cr}$ in Dle and $\mathrm{Cu}>\mathrm{Ni}>\mathrm{Cr}>\mathrm{Co}>\mathrm{Cd}>\mathrm{pb}$ in Aleta wendo wereda.

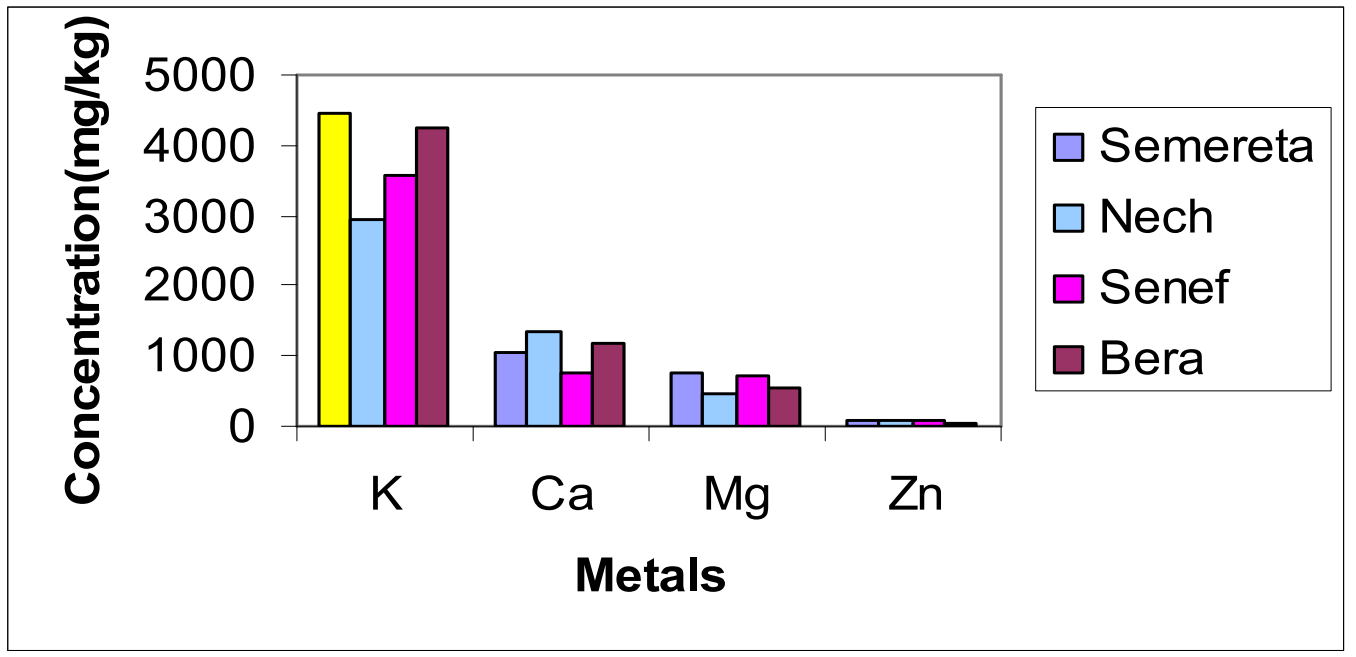

Figure 4a.The Relative concentration of macronutrients and $\mathrm{Zn}$ in the barley varieties.

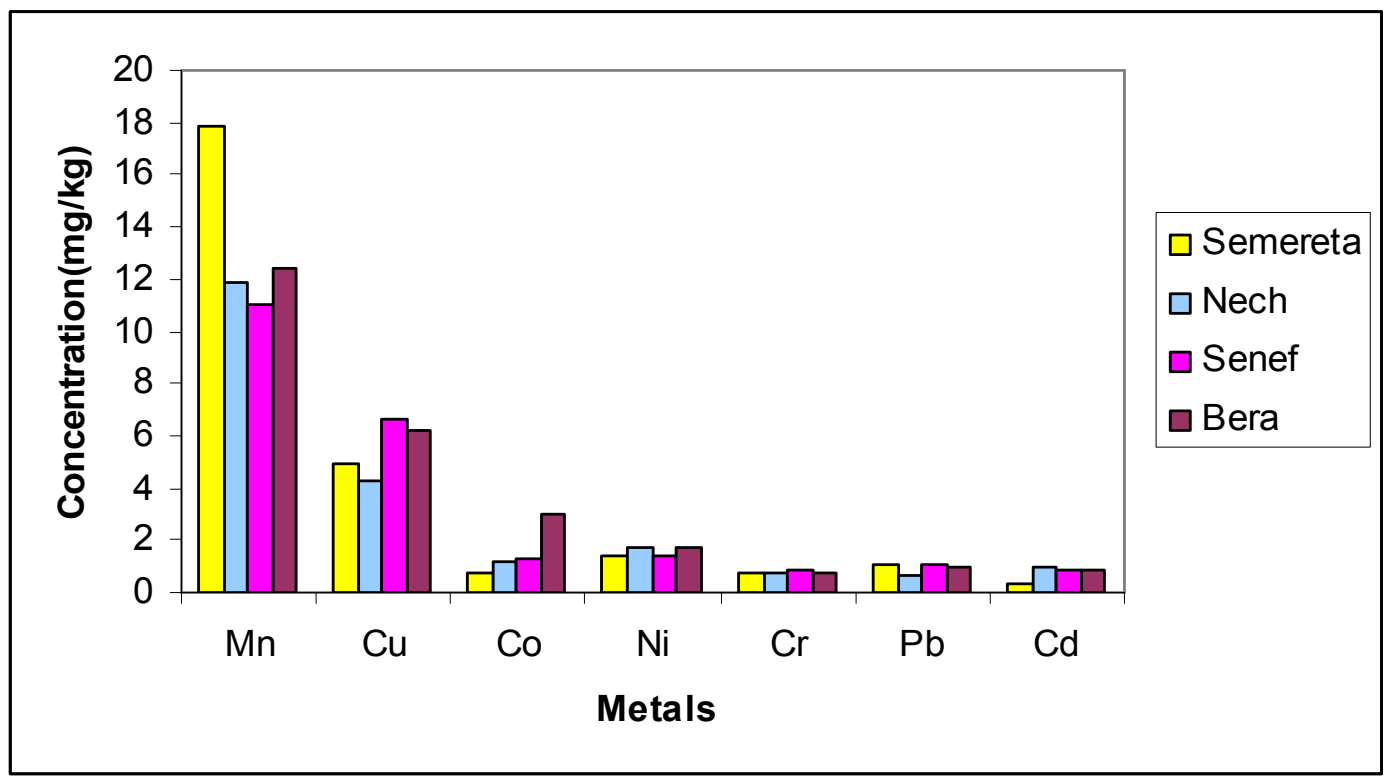

Figure $4 \mathrm{~b}$. The Relative concentration of trace metals in the barley varieties. 


\section{Calcium, Magnesium and Potassium concentration in barley varieties}

All of them as they are macro elements are found in large amount than the rest. As can be seen from the trends, in table 8 and Figure (6) above, barley serves as a good source of essential metals to human and animals. All barley types contain higher amount of the macronutrients $(\mathrm{K}, \mathrm{Ca}$, and trace $\mathrm{Zn}$, except $\mathrm{Mg}$ ). A high accumulation of calcium, magnesium and potassium relative to the others is due to their higher natural abundance in the soil.

Covered barley (Smereta and Nech) contains more calcium than hull less barley due to the hull composition. There for these study shows that to full fill the daily calcium requirement, barley varieties has enough sources or could be a supplements, except Senef gebse (partially hulled), which has low content of calcium.

The reduction in concentration of $\mathrm{Mg}$ in barley plant coupled with an increase in $\mathrm{Ca}$ may be due to $\mathrm{Ca}$ reduce movement of $\mathrm{Mg}$ from the root to the shoot is presumably due to replacement of $\mathrm{Mg}$ for $\mathrm{Ca}$.

Zinc, manganese and copper concentration in barley varieties

As can be seen from Figure $6 \mathrm{a}, \mathrm{Zn}$ is the most concentrated from essential and toxic metals in all barley types with values of $44.55-82.39 \mathrm{mg} / \mathrm{kg}$. The zinc content of barley species greatly differs along with the geographical area. In Semereta species $68.66 \mathrm{mg} / \mathrm{kg}$ in Dale and $46.41 \mathrm{mg} / \mathrm{kg}$ in Aleta wondo; Bera species also has $82.39 \mathrm{mg} / \mathrm{kg}$ in Aleta wendo and $44.55 \mathrm{mg} / \mathrm{kg}$ in Dale wereda. This signifies that the zinc content of barley species is highly dependent on the environment. Most probably it may be due to the different in the rain fall in the two weredas the soil type. Except Semereta in both weredas the zinc content being high, while the cadmium content is lower, shows of the metals present in the soil solution $\mathrm{zn}$ is most likely to compete with Cd up take.

Water is the most precious agricultural resource after land in the water-limited environments. Zinc concentration in grains was significantly affected by water stress. The $\mathrm{Zn}$ concentration increased to its highest level may be due to water stress to barley seedlings. The trend of $\mathrm{Zn}$ increment in all four barley varieties was more pronounced. The application of severe drought stress raised the mean $\mathrm{Zn}$ concentration to its maximum level of $82.39 \mathrm{mg} \mathrm{kg}^{-1}$. There for except Semereta barley types have severed zinc toxicities.

In the present study the manganese content of different barley species is in the range of $11.00-20.35 \mathrm{mg} / \mathrm{kg}$, which has a good agreement with the literature value. The international program on chemical safety, World Health Organization, Geneva, 1981, also recommend Mn concentrations in certain cereals, nuts, and shellfish can be much higher, exceeding $30 \mathrm{mg} / \mathrm{kg}$ in some cases. In cereal crops from the USSR, manganese concentrations varied from 2 to $100 \mathrm{mg} / \mathrm{kg}$. According to the WHO (1993) all barley species could be the best Mn supplement.

Manganese concentration increased with water stress intensity. The mineralization rate would be accelerated at drought stress conditions because of higher oxidation rate. Grain Mn concentrations generally reflect soil exchangeable $\mathrm{Mn}$, genetic factor and $\mathrm{pH}$. When the soil $\mathrm{pH}$ reaches 7 or less because of environmental conditions, the availability of $\mathrm{Mn}$ will increase in soil as well as in plant tissue. The present study shows the $\mathrm{Cu}$ content to be in the range of $3.72-6.62 \mathrm{mg} / \mathrm{kg}$ or consumption at $450 \mathrm{~g} / \mathrm{day} / \mathrm{p}$ is $1.67-2.98 \mathrm{mg}$.

Nickel, chromium and cobalt concentration in barley varieties

The daily intake of nickel via foodstuff is estimated at $0.15-0.7 \mathrm{mg} /$ day (Codex, 1995) and the average daily intake is $15-20 \mathrm{mg}$ /day (WHO, 1993). There for according to WHO, 1993 the Ni content of all barley varieties has some toxicity. The most probable cause may be, microelements such as nickel can get into plants easily, since the exchangeable Ni content of the soil increase with the increasing soil acidity and Ni absorption is increased due to the increase in phosphate content of the soil.

Recent estimates of the daily intake of $\mathrm{Cr}$ range from $0.025-0.2 \mathrm{mg} / \mathrm{day}$ (Codex, 1995). According to the Codex, 1995, the small amount of chromium found in all barley varieties does not contradict with the requirement of the metal for proper functioning of the body. The estimated intake of cobalt is 0.2 to $1.8 \mathrm{mg} / \mathrm{day}$ (Codex, 1995). The present study shows that the cobalt content to be in the range of $0.75-3.03 \mathrm{mg} / \mathrm{kg}$, so all barley species could be the best supplement of cobalt with no toxicities.

\section{Cadmium and lead concentration in barley varieties}

In barley grain the maximum permissible concentration of $\mathrm{Cd}$ is $0.1 \mathrm{mg} \mathrm{kg}^{-1}$ and $0.2 \mathrm{mg} \mathrm{kg}^{-1}$ for $\mathrm{Pb}$ (European Commission 1999). But in the present study the barley concentration of $\mathrm{Cd}$ and $\mathrm{Pb}$ varies between 0.204$1.18 \mathrm{mg} / \mathrm{kg}$ and $0.43-1.14 \mathrm{mg} / \mathrm{kg}$ respectively, which is above the permissible range of the European commission. According to the Poland ministry of health the maximum allowable concentration of lead and cadmium in barley is 0.2 and $0.1 \mathrm{mg} / \mathrm{kg}$ respectively. There for this study shows that all varieties has some toxicities of $\mathrm{Pb}$, since there is no significance difference between he varieties. Even Semereta has significant amount up to $1.23 \mathrm{mg} / \mathrm{kg}$. On the other hand the cadmium content of Nech barley has reached up to $1.18 \mathrm{mg} / \mathrm{kg}$ toxicities level. The increase in cadmium, $\mathrm{Cd}$ readily taken up by plants and lead concentration most probably may be due to high natural abundance in the soil, in localized mineral zones, or around volcanoes an elevated level of the elements arsenic, lead, cadmium, copper and zinc can also be found.

\subsection{Comparison of Metals Concentration in barley with Literature Value.}

The comparison of the metal concentrations determined in this study and the reported values from these 
researchers are presented in table 9. Because of the origin, type of barley varieties and sample preparation techniques used by the researchers were different, it is not reasonable to compare, it is important to see the results from this study with the previous studies for qualitative purpose regardless of all the above differences. From the table 9, one can see that the concentration of calcium determined in this study is comparable with the values reported in CAN, USA, UK, and NRC for all barley varieties, but the Nech varieties is the highest from the reported value. The potassium content also found to be similar with the reported value, but the $\mathrm{Mg}$ content is harshly low. The zinc content of all barley varieties included in this study is of higher with those values reported in table 9.

Table 9: Comparison of observed metals concentration for macro elements ( $\mathrm{g} / \mathrm{kg})$, for trace metals $(\mathrm{mg} / \mathrm{kg})$, in barley crop with reported values.

\begin{tabular}{|c|c|c|c|c|c|c|}
\hline Institute & \multicolumn{6}{|c|}{ Metallic elements } \\
\hline & $\mathrm{Mg}$ & $\mathrm{K}$ & $\mathrm{Ca}$ & $\mathrm{Zn}$ & $\mathrm{Mn}$ & $\mathrm{Cu}$ \\
\hline Morghan* & $0.9-1.6$ & $3.5-6.3$ & $0.5-1.6$ & $19-37$ & $5-47$ & $3.5-19.8$ \\
\hline $\mathrm{CAN}^{\mathrm{a}}$ & $1.5 \pm 0.2$ & $5.4 \pm 1.8$ & $0.6 \pm 0.2$ & $42.3 \pm 10.5$ & $18.9 \pm 6.7$ & $5.4 \pm 2.4$ \\
\hline $\mathrm{USA}^{\mathrm{a}}$ & $1.4 \pm 0.02$ & $6.3 \pm 0.11$ & $0.7 \pm 0.02$ & $38.0 \pm 7.0$ & $22.0 \pm 6.0$ & $7.0 \pm 2.0$ \\
\hline $\mathrm{UK}^{\mathrm{a}}$ & $1.2 \pm 0.2$ & $5.0 \pm$ & $0.9 \pm 0.06$ & $32.5 \pm 8.5$ & 18.53 .6 & $4.2 \pm 1.5$ \\
\hline $\mathrm{NRC}^{\mathrm{a}}$ & 1.5 & 4.7 & ---- & 17.1 & 18.0 & 9.0 \\
\hline My study & $0.483-0.757$ & $2.954-4.434$ & $0.74-1.347$ & $44-82$ & $11-20$ & $3.72-6.88$ \\
\hline
\end{tabular}

CAN data from Alberta (Suleiman et al, 1997); USA, pooled data from the state of New York, Indiana, Idaho and Arizona (Berger, 1995); $\mathrm{UK}^{\mathrm{a}}$ data from the ministry of agriculture, fisheries and food (MAFF, 1990). Morgan DE 1967 and 1968 J.sc.FD agric.; 18, 21; 19,393. 'European Commission 1999.

\begin{tabular}{|l|l|l|l|l|l|l|l|}
\hline Institute & $\mathrm{Cu}$ & $\mathrm{Co}$ & $\mathrm{Ni}$ & $\mathrm{Cr}$ & $\mathrm{Pb}$ & $\mathrm{Cd}$ & $\mathrm{R} . \mathrm{F}$. \\
\hline WRI & $\mathbf{7 . 7 2 \pm 0 . 8 1}$ & $3.60 \pm 0.48$ & $2.89 \pm 0.33$ & $1.22 \pm 0.09$ & $1.27 \pm 0.02$ & $0.23 \pm 0.04$ & {$[2]$} \\
\hline NARC & $7.54 \pm 0.65$ & $4.05 \pm 0.51$ & $1.19 \pm 0.11$ & $2.81 \pm 0.23$ & $1.30 \pm 0.02$ & $0.24 \pm 0.02$ & {$[2]$} \\
\hline Pakistan & $7.57 \pm 0.32$ & $3.60 \pm 0.20$ & $4.22 \pm 0.19$ & $1.13 \pm 0.19$ & $1.04 \pm 0.13$ & $0.43 \pm 0.04$ & {$[1]$} \\
\hline H.U & $3.72-6.88$ & $0.75-3.03$ & $1.305-1.86$ & $0.66-0.12$ & $0.43-1.23$, & $0.204-1.18$ & $\mathrm{ps}$ \\
\hline
\end{tabular}

$\mathrm{WRI}^{\mathrm{a}}=$ wheat research institute, $\mathrm{NARC}^{\mathrm{b}}=$ national agriculture research center, $\mathrm{PS}=$ present study H.U. = Hawassa university.

\subsection{Analysis of variance}

In this study, samples were collected randomly from each geographical area from where they are commercially available in the market for both study sites and one representative bulk sample was prepared. During this processes a number of random errors may be introduced in each sample. Therefore the differences $(P<0.05)$ among the four varieties may be attributed primarily to genetic background, since all varieties were grown under the same environmental conditions.

In all these barley varieties there are two possible sources of variation. The first, which is always present, is due to the random error in measurement. It is this error which causes a different result to be obtained each time a measurement is repeated under the same conditions. The second possible source of variation is due to what is known as a controlled or fixed-effect factor. A statistical method is used to check whether there is contribution from these random errors for difference in results of analysis or not. If there are differences, statistical analysis will tell us whether the differences are significant or not at a specified confidence level.

One -way Analysis of Variance (single factor-ANOVA) was used to perform the statistical analysis by assuming as barley varieties are independent and concentration of the metals is dependent variable to test whether there are significant differences between means of each barley types at the stated confidence level or not. For analysis of ANOVA SPSS soft ware used to compare the statistical parameters and the result are shown in table 10 and 11.

Table 10: Analysis of variance (ANOVA) between samples of the four barley types

\begin{tabular}{|l|l|l|l|l|l|l|l|l|l|l|l|}
\hline \multicolumn{1}{|c|}{} & \multicolumn{1}{l|}{ Metals compared at 95\% confidence level } \\
\hline Metals & $\mathrm{K}$ & $\mathrm{Ca}$ & $\mathrm{Mg}$ & $\mathrm{Zn}$ & $\mathrm{Mn}$ & $\mathrm{Cu}$ & $\mathrm{Co}$ & $\mathrm{Ni}$ & $\mathrm{Cr}$ & $\mathrm{Pb}$ & $\mathrm{Cd}$ \\
\hline F3,8(4.066) & 23.15 & 13.6 & 41.66 & 6.42 & 32.6 & 9.60 & 41.43 & 1.02 & 1.585 & 1.92 & 85.69 \\
\hline P(sig.) & 0.000 & 0.002 & 0.000 & 0.016 & 0.000 & 0.05 & 0.000 & 0.430 & 0.268 & 0.205 & 0.000 \\
\hline
\end{tabular}

Thus, from the result shown in table 10, under F value, there is statistically Significant differences between the means of the different samples at 95 percent confidence level except $\mathrm{Cr}, \mathrm{Pb}$ and $\mathrm{Ni}$. This $\mathrm{F}$ statistic indicates there is difference between the means of the four barley types, for each respective metal, but does not indicate where the differences are. To be more specific a multiple comparison using least significant difference test has done; the difference of the means of barley types has compared with the least significant difference value. The result of this multiple comparison is tabulated as in table 11. The table shows the significance $p$ values for each 
comparison.

Table 11: Results of least significance test for the comparison between the means of the four barley types.

\begin{tabular}{|l|l|l|l|l|l|l|l|l|l|l|l|}
\hline varieties & \multicolumn{10}{|c|}{ Metals Compared at 95\% confidence level and their p-value } \\
\hline & $\mathrm{K}$ & $\mathrm{Ca}$ & $\mathrm{Mg}$ & $\mathrm{Zn}$ & $\mathrm{Mn}$ & $\mathrm{Cu}$ & $\mathrm{Co}$ & $\mathrm{Ni}$ & $\mathrm{Cr}$ & $\mathrm{Pb}$ & $\mathrm{Cd}$ \\
\hline $\mathrm{Sm}, \mathrm{N}$ & 0.000 & 0.01 & 0.000 & 0.193 & 0.000 & 0.844 & 0.317 & 0.247 & 0.728 & 0.071 & 0.000 \\
\hline , S & 0.002 & 0.022 & 0.289 & 0.538 & 0.000 & 0.004 & 0.129 & 0.136 & 0.492 & 1.000 & 0.000 \\
\hline , B & 0.392 & 0.188 & 0.000 & 0.020 & 0.000 & 0.012 & 0.000 & 0.252 & 0.224 & 0.481 & 0.617 \\
\hline $\mathrm{N}, \mathrm{S}$ & 0.016 & 0.000 & 0.000 & 0.073 & 0.208 & 0.003 & 0.548 & 0.695 & 0.728 & 0.071 & 0.173 \\
\hline ,B & 0.000 & 0.090 & 0.169 & 0.003 & 0.641 & 0.009 & 0.000 & 0.989 & 0.173 & 0.218 & 0.000 \\
\hline S, B & 0.008 & 0.03 & 0.000 & 0.055 & 0.101 & 0.419 & 0.000 & 0.685 & 0.076 & 0.481 & 0.000 \\
\hline
\end{tabular}

$\mathrm{Sm}=$ semereta, $\mathrm{S}=$ Senef, $\mathrm{N}=\mathrm{Nech}, \mathrm{B}=$ Bera

No significant difference in the levels of $\mathrm{Zn}, \mathrm{Cu}, \mathrm{Co}, \mathrm{Ni}, \mathrm{Cr}, \mathrm{Pb}(\mathrm{p}=0.193,0.844,0.317,0.247,0.728$, 0.071); Mg, Zn, Co, Ni, Cr, Pb (p = 0.289, 0.538, 0.129, 0.136,0.492, 1.00) and K, Ca, Ni, Cr, Pb, Cd (P = 0.392, $0.188,0.252,0.224,0.481,0.617)$ between semereta and nech, semereta and senef, semereta and bera respectively at $95 \%(\mathrm{p} \leq 0.05)$ Confidence level. In addition there is no significance difference in $\mathrm{Zn}, \mathrm{Mn}, \mathrm{Co}, \mathrm{Ni}$, $\mathrm{Cr}, \mathrm{Pb}, \mathrm{Cd}(\mathrm{p}=0.073,0.208,0.548,0.695,0.728,0.071,0.173) \mathrm{Ca}, \mathrm{Mg}, \mathrm{Mn}, \mathrm{Ni}, \mathrm{Cr}, \mathrm{Pb}(\mathrm{P}=0.09,0.169,0.641$, $0.989,0.173,0.218)$ and $\mathrm{Zn}, \mathrm{Mn}, \mathrm{Cu}, \mathrm{Ni}, \mathrm{Cr}, \mathrm{Pb}(\mathrm{P}=0.055,0.101,0.419,0.685,0.076,0.481)$ between nech and senef,nech and bera ,and senef and bera respectively at $95 \%(\mathrm{p} \leq 0.05)$ Confidence level. Either of this, there is significant difference between each varieties.

However, significant differences are observed between varieties in the level of some metals, More specifically stastical comparisons between varieties shows that (table 10 and 11) between the Ca content of barley varieties as there is significant difference except between semereta and bera, nech and bera varities. This revealed that the calcium content is higher in semereta, nech and bara varities.similarly the stastical table shows that as there is higher content of $\mathrm{Mg}$ in semereta and senef, while nech and bera are the lowest. But for $\mathrm{Ni}, \mathrm{Cr}$ and $\mathrm{Pb}$ the is no significance difference between all varities at aspecified confidence level. From table 10 and 11 , the difference in the level of respective metal content of the four barley types could be attributed to the chemical composition of each barley type, genetic factors and the specific environmental conditions in which the barley was cultivated

\section{Conclusions and recommendation}

The chemical analysis of cereal crops is an important part of quality assurance program in food processing. It is also important to understand the mineral content of animals feed, where barley is the main supplement of grass. This study will be help full to know related health problems related to the variation of metal concentrations in food.

It could be recommended that this study will help for farmers to cultivate improved varieties for their mineral composition like semereta and nech varieties has higher content of $\mathrm{Ca}$ than senef varieties. The decrease in concentration of $\mathrm{Mg}$ with increasing $\mathrm{Ca}$ was presumably due to competition between the two cations for neutralization of negative charges within the exchange sites. Therefore Barley foods should be supplemented with $\mathrm{Mg}$ rich foods to full fill the $\mathrm{Mg}$ daily requirement. The calcium content of Senef gebse should be also supplemented with calcium riche foods.

It can be concluded that water deficiency is able to enhance nutritional value of $\mathrm{Mn}$ and $\mathrm{Zn}$ in drought stressed conditions, but decrease severely the magnesium content. The Copper deficiency can also be corrected either by adding a copper salt to the soil or spraying it to the crop itself. From this study, we can say that the $\mathrm{Zn}$ content of the barley varieties is significantly higher than the $\mathrm{Zn}$ requirement, there for the content should be reduced to remove toxicities of zinc (probably acid washing of barley could decrease the Zn content).

From the selected elements, cobalt, chromium and nickel; all barley species could be the best supplement of cobalt and chromium with no toxicities. Therefore the toxicities ( $\mathrm{Cd}$ and $\mathrm{Pb}$ ) known from barley would have problem for humans and animals feed.

\section{Reference}

1. S. Maleki Farahani, M. R. Chaichi, D. Mazaheri, R. Tavakkol Afshari, and Gh. savaghebi. Barley grain minerals analysis as affected by different fertilizing systems and by drought stress, journal of agricultural science and technology, (2011) vol.13:315-326.

2. Kifilu Tarekegn Abera (2009). Agronomic evaluation of ethiopian barly (hordeum vulgare L.) landrace populations under drought stress conditions in law rain fall areas of Ethiopia.

3. G. Q. Shar, L. A. Shre, T. G. Kazi, H. I. A. fridi, M. B. Arain, M. K. Jamali (April 2007), Determination of trace and toxic elements in four pakistanibarly (hordium vulgare L.) varities and its soil collected from pirsabak, Pakistan, journal of research science bahauddin zakariyauni,18(2) 53-59.

4. E. E. Golia, A. Dimirikou, I. K. Mitsios (2009). Heavy metal concentration in tobacco leaves in relation to 
there available soil fractions, Plant Science and Soil Analysis, 40:106-120.

5. Ali B. Ishaque, Linda Johnson, Tonya Gerald, Dwayne Boucaud, Joseph Okoh, and Paul B. Tchowunwon. Assesment of individual and combined toxicities of four metals (as,cd,hg,and pb) in the microtox assay, international journal of environmental research and public health, 2006,3(1), 118-120.

6. Roger Villanuava, Paco Bustamante. Compositin in essential and non essential elements of early stages of cephalopods and dietary effects on the elemental profile of octopus vulgaris paralarva, aqua culture, 261(2006) 225-243.

[7] Stefan A. E. Kools, Marie-Elene Y. Boivin, Andre W. G. Van Der Wurff, Matty P. Berg, Cornelis A. M. Van Gestel, Nico M. Van Straalen. Assessment of structure and function in metal polluted grass lands using terestrial mode ecosystems, ecological and environmental safety, 72(2009), 51-59.

8. K. O. Soetan, C. O. Olaiya and O. E. Oyewole. The importance of miniral elements for humans, domestic animals and plants: African journal of food science, vol. 4(5), pp.200-222, may 2010.

9. Zewdie, barley types in Ethiopia, http://www.idrc.ca/en/ev-98727-201-1-DO_TOPIC.html, accessed on 21 Nov 2010 06:09:00 GMT.

10. Prof. Dr. Jens Leon, prof. Dr. Mathias Becker (April 2010). Genetic diversity and population differentiations analysis of Ethiopian barley (hordoum vulgare L.) land races using morphological traits and SSR markers.

11. H.gebrie and j.vanleur (1993). Barly research in Ethiopia: past work and future prospect, institution of agricultural research.

12. Byung-kee Baik, Teven E. Ullrich. Barley for food: characteristics improvement and renewed interest, journal of cereal science, 48(2008) 233-242.

13. Food barly. Stefania Grando, Helena Gomezmachpherson (2005). Food barley: importance uses and local knowledg, international center for agricultural research in the dry areas.

14. M. L. Adams, S. P. Mcgrath, and F. J. Zhao, F. A. Nicholson, A. H. Sinclair. Lead and cadmium as contaminants in U. K. wheat and barley.

15. Amare Hailu (august 2007). Metal concentration in vegetables grown in northern Addis Abeba and part of rift valy (Ziway), Ethiopia.

16. E. W. Russell. Soil condition and plant growth (1973). 10th ed., 606-640.

17. T.Mahmood, K. R. Islam, S. muhammad (2007). Toxic effects of heavy metals on early growth and tolerance of cereal crops, Pakistan Journal of Botanist, 39(2): 451-462.

18. Stanley E. Manahan (2000). Environmental chemistry, Washington D. C. 7TH Ed.

19. k. kulp, j. G. poute, Jr. (2004). Hand book of cereal science and thechnolgy, 2nd edi. 96-107.

20. Abdel-Fattah A. A., Ei-Sayed (2005). Improvement of food hull less barley in Egypt, international center for agricultural research in the dry areas.

21. J. ones, J. Park, T. Owling, D. Phares, J. Young (2006). Role of potassium excretion and percent body fat on ethnic differences in plasma aldosterone levels, Vol.16

22. B. Barefoot (1998). The Importance of Calcium.

23. M.Schachter, M. D., F.A.C.A.M (1996). The importance of Magnesium to Human Nutrition.

24.Gabriela N., Adask A., Juraj Lesny, Ivan Michali 'K. Environmental aspect of manganese chemistry, Department of Biotechnology, University of SS. Cyril and Methodius, Slovakia.

25. Copper Development Association (1984). Copper and Human Health - A Review Technical Note 34.

26 Rajendran Sellamuthu, Christina Umbright, Rebecca Chapman, Stephen Leonard, Shengqiao Li, Michae Kashon and Pius Joseph, Transcriptomics Evaluation of Hexavalent Chromium Toxicity in Human Dermal Fibroblasts, J Carcinogene Mutagene 2011.

27. Dr Peter Baum. Guidelines on metals and alloys used as food contact materials technical document, Council of Europe

28. S., S., O., K, A., L., K (2005). The effect of cadmium and lead pollution on human and animal health, Supplementum, 531-532.

29. Smirjdkova, S., Ondrasovicovd O., Kaskova, A., Laktiiovd, K. The effect of cadmium and lead pollution on human and animal health, University of Veterinary Medicine, Supplementum 5, 31-532, 2005.

30. Demelash Biffa, Etana Debela, Fekadu Beyene. Prevalence and Risk Factors of Mastitis in Lactating Dairy Cows in Southern Ethiopia, International Journal of Appliedand Research of Veternary Medicine Vol. 3, No. 3, 2005.

31. Anteneh Gebremariam (June, 2010). Farmers' Awareness about Land Degradation and their Attitude towards Land Management Practices, Addis Ababa University School of Graduate studies.

32. Kebede Ganole (april 2010). Gis- based surface irrigation potential asssessment ofriver catchments for irrigation development in Dale woreda, sidama zone, SNNP.

33. Environmental protection agency (February, 2007). Flame atomic absorption spectrophotometey, method 7000B, Revision 2.

34. Skoog. Holler. Nieman (1998). Principles of instrumental analysis, 5th edi., 3-235. 
35. K. Lorenz, G. Macfarland, and J. Maga. Research note on pressure digestion of cereal grains and flours for mineral analysis by atomic absorption, cereal chemistry 54 (20):281-286.

36. Dr. C. Owen Plank (May 1992). Plant analysis reference procedures for the southern region of the United States; plant Analysis Reference Procedures for Southern U.S. \# 368)

37. K. Skroch, C. Hoffman, L. Mundt, R. Gelderman (1999). Plant analysis procedures, Dakota State Soil Testing and Plant Analysis Laboratory, plant science prompeth.

38. Kirsten J. Anderson, Monika I. Kisser (august 3003). Digestion of solid matrices

Desk study - horizontal, Denmark.

39. Atomic (flame) emission spectrometry, file://c|c/documents\%20and $\% 20$ setting s/cfjpb/my\%20...websit/teaching/ia/iaprojects/atomic emission.htm (1of 4). Accessed on [9/12/2002 10:33:35 AM].

40. Environmental protection agency (July 1992). Atomic absorption methods, EPA method 2007A, revision 1.

41. G. H. Jefffery, J. Basseff, J. Mendham, R. C. Denney (1989). Vogle's text book of quantitative chemical analysis, fifth edition.

42. McGraw-Hill hand books (2004). Deans analytical chemistry hand book, 2nd edition ,digital engineering libraray@McGraw-hill.

43. Minaleshewa Atlabachew (July 2007). Studies on Commercially available enset (Ensete ventricosum, Chessman) food Products (Kocho and Bulla) for Major, Minor and Trace Elements.

44. S.TRA, R. Brukh (2003). Sample preparation in an analytical Chemistry, Chemical Analysis, 162: 6-14.

45. Kerilynn M. Carden (December 1998). Method detection limit survey results and analysis, Wisconsin Department of Natural Resources Laboratory Certification Program

46. Clarissa s. p. De Castro, Andrea, F. Arruda, Leandro R. Da Cunha, Jurandir R. Souza De, jez w. b. Braga and Jose $\mathrm{G}$. Dorea. Toxic metals $(\mathrm{Pb}$ and $\mathrm{Cd})$ and there respective antagonists $(\mathrm{Ca}$ and $\mathrm{Zn})$ in infant formulas and milk marketed in brassilia, brazi, international journal of environmental research and public health 201 47.

47. United States consumer product safety commission directorate for laboratory sciences. Standard operating procedure for determining total lead in children's metal products, December 2008.0, 7, 4062-4077.

48. James N Miller \& Jane C Miller. Stastics and chemo metrics for analytical chemistry. fifth edition.

49. P. R. Shewry (1992). Barley genetics, biochemistry molecular biology and biothecnology.

50. GraNt, C. A. and RAcz, G. J. 1987. The effect of ca and Mg concentrations in nutrient solution on the dry matter yield and $\mathrm{Ca}, \mathrm{Mg}$ and $\mathrm{K}$ content of barley (Hordeum vulgare L.). Canadian Journal of Soil Science, 67: 857-865.

51. R. G.Gerritse, W. Vandriel, K. W. Smilde and B. Vanluit. Uptake of heavy metals by crops in relation to there concentration in the soil solution, plant and soil, 75,393-404(1983). 